\title{
AGUSTIN L. OCAMPO. UN ESCULTOR OLVIDADO
}

\section{Por Elisa Garcia Barragdn}

Al grupo de escultores académicos mexicanos, naturalistas y asaz románticos de fines del siglo xix y principios del presente, integrado por Jesús Contreras, Enrique Guerra y Fidencio L. Nava, hay que añadir el nombre de otro discípulo de la Escuela Nacional de Bellas Artes: Agustín L. Ocampo, autor de la escultura Desespoir que ornamenta en la actualidad la Alameda Central de la ciudad de México y que, durante muchos años, ha sido atribuida a Jesús Contreras.

Muy pocos son los datos que existen acerca de este artista; el año de 1891 en la vigesimosegunda exposición de la Escuela Nacional de Bellas Artes, presenta sus primeros trabajos: "dibujos nocturnos tomados del yeso, dibujos de ornato diurnos y nocturnos y dibujos tomados de la estampa" realizados bajo la orientación de sus maestros Santiago Rebull, Félix Parra y Jesús Contreras; también un grupo de esculturas: Cabeza de ninfa; busto del Amor; Cabeza de niño; Torso de Ilisus (sic); estatua de Niño con máscara; estatua de Fauno bailando y los bustos Flor marchita y flor lozana. 1

A pesar de que esas obras no tuvieron mayor resonancia, su aplicación y talento sí fueron pronto reconocidos y, para el año de 1898, se encuentra pensionado por el gobierno federal en París. Para justificar su pensión, ese mismo año envía a la vigesimotercera exposición la escul. tura que llama Pescador.

Gracias al comentario que en torno a la obra escultórica mexicana presentada en la Exposición Internacional de París de 1900, escribió Carlos Díaz Dufoo para la revista El Mundo Ilustrado de 28 de octubre de 1900, puede afirmarse que es obra suya la escultura Desespoir. Este conocido y prestigiado periodista que fuera en 1913 director del periódico El Imparcial, en su artículo "Recuerdos de la Exposición. Un escultor mexicano", después de hacer interesantes reflexiones sobre la extraordinaria obra de Rodin, en las que lo considera liberador de la escultura del peso de los convencionalismos, pasa a comentar el encuentro que en París tuvo con Jesús Contreras y sus alumnos Cárdenas, Nava

1 Romero de Terreros, Manuel. Catálogo de las exposiciones de la antigua Academia de San Carlos de México (1850-1898). México, UNAM, IIE, 1963 (Serie de Estudios y Fuentes del Arte en México, vol. xiv). 
y Ocampo. De este último, su obra lo impresionó tan vivamente, que le dedicó el mencionado artículo:

Entonces conocí a Ocampo, entonces comprendí el porqué de la sinceridad cruel y dolorosa de su escultura Desesperación, que tan brillantemente ha figurado en el salón de Bellas Artes del Pabellón Mexicano en el Certamen Universal.

Es que Ocampo sólo ha tenido necesidad de bucear en sus sufrimientos, que descender por la escala de la inspiración a la sima de sus tristezas.

Hace referencia a las muchas penurias sufridas por el joven pensionado:

Pequeña pieza de estudiante pobre o de artista que comienza; ¡cuántas noches faltan dos leños que arrojar en la chimenea, que abre inútilmente su bocaza negra! Y al día siguiente, ja la labor ; la dejar escritos en la piedra los dolores, estas injusticias, a develar estas páginas!, iy cuántas de estas noches, joven artista, la desesperación no habrá llamado a tu puerta, y te habrá acompañado como una hermana vestida de negrol Así nació ese incisivo trozo de mármol, así brotó esa escultura punzante. Hija de la vida, producto de esa escuela de artistas nuevos, a los que Rodin ha marcado una senda. Desesperación es un "sucedido", un documento, un dato más que agregar a esa historia que la gacetilla narra inconscientemente en su tarea baladi. ¿Qué es todo ello, después de todo? Una mujer que se abate sobre el piadoso regazo de la tierra.

En efecto, tras esta bella escultura romántica, cuyo dramatismo se aminora por la armonía y la leve sensualidad de las formas, está la sombra de Rodin, del Rodin más delicado y sentimental.

Desespoir triunfa en Paris, pero la mala suerte persigue a Agustín L. Ocampo, la personalidad de su maestro Jesús Contreras, y el éxito de su Malgré Tout es de tal magnitud que la crítica mexicana se ha olvidado de mencionar a Ocampo, y le ha atribuido en varias ocasiones a Contreras la escultura Desespoir. Afortunadamente el testimonio de Diaz Dufoo permite reconocer a Ocampo, como el escultor de esta hermosa obra romántica que nos seduce al pasear por la ahora remozada Alameda Central de México. 


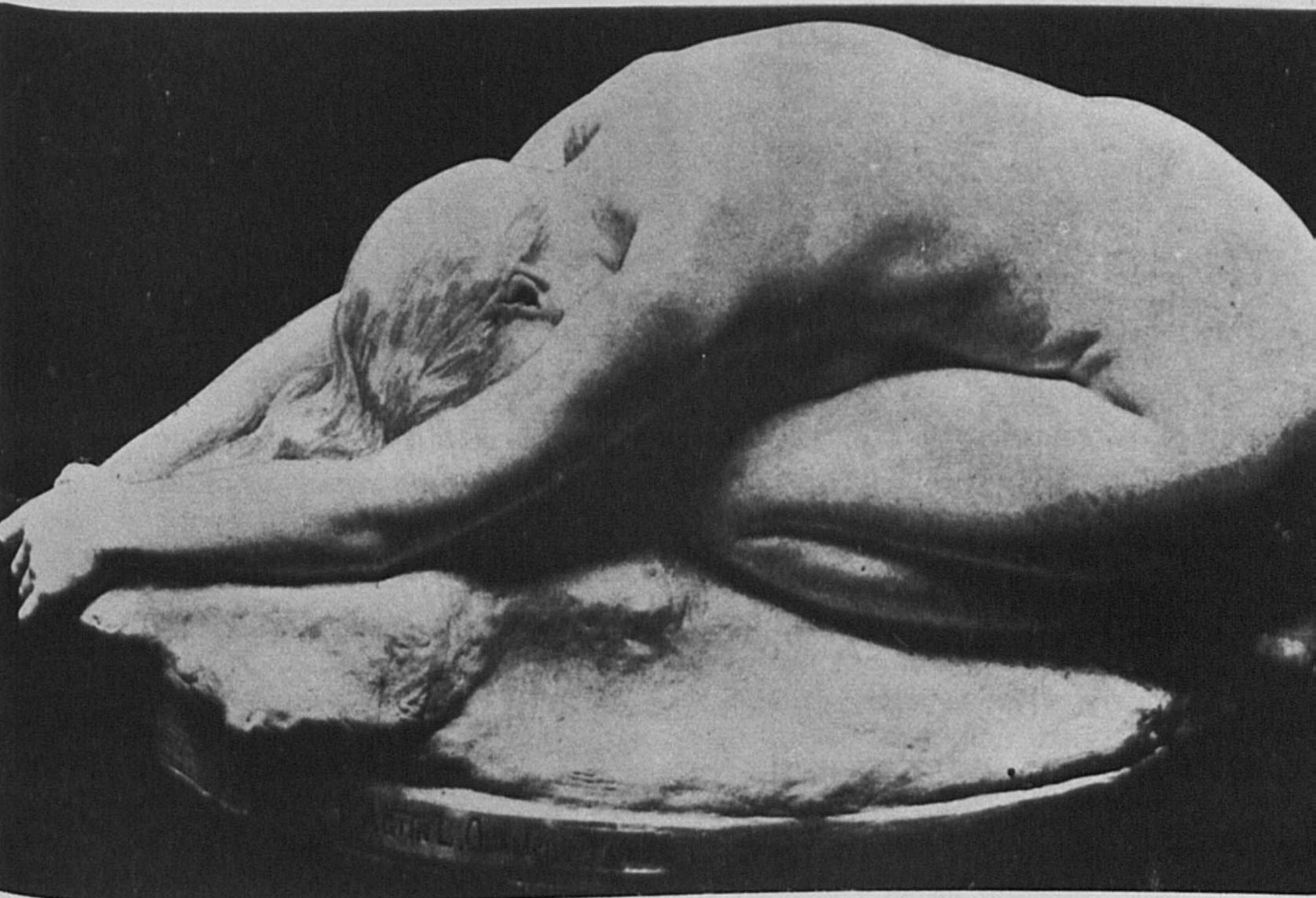

1. Desespoir. Escultura de Agustín L. Ocampo. Fotografía tomada de El Mundo Ilustrado, de 28 de octubre de 1900. 